\title{
The Experience of Dual Career through Slovak Athletes' Eyes
}

Authors' contribution:

A) conception and design of the study

B) acquisition of data

C) analysis and interpretation of data

D) manuscript preparation

E) obtaining funding

\author{
Kristina Geraniosova $^{\text {A-D }}$, Noora Ronkainen ${ }^{\text {A,C,D }}$
}

Aarhus University, Denmark

ABSTRACT

The purpose of this study was to examine how Slovak athletes experience dual career (the combination of an athletic career with education and/or work). The study strived to gain an understanding of the athletes' attitudes towards education as well as perceived difficulties and supporting elements in pursuing dual career. Five athletes were interviewed once for approx. $105 \mathrm{~min}$. The interviews and data analysis were based on Intepretative Phenomenological Analysis (IPA) and the interviews were focused on their experience in combining an athletic career with education or work. The athletes experienced dual career as manageable as long as they were assisted by at least simple supportive structures and provided flexible arrangements. Peers had played an important role in athletes' decision-making concerning dual career and in providing social support when facing challenges within dual career. The teachers' prejudice against the athletes based on their athletic role and the lack of dual career structures appeared to be significant deficiencies in dual career support. Finally, the analysis revealed the negative perception of athletes and sport science students by educational representatives. This perception may be a hurdle to be overcome in future dual career development.

athletic career, education, work, interpretative phenomenological analysis, lived experience

\section{Introduction}

The concept of dual career concerns the combination of an athletic career with education and/or occupation. Pursuing education while competing in high-performance sport can be a challenging task - the increasing demands on athletic performance in elite sports places high pressure on young athletes, who may feel they are forced to choose between maximizing their athletic potential or obtaining a satisfying education for a post-athletic career (Lavallee \& Wylleman, 2000). This, in turn, often leads to premature discontinuation of the athletic career due to priorization of education (Amara, Aquilina \& Henry, 2004), or to lower investment in education due to focus on athletic success (Aries, McCarthy, Salovey \& Banaji, 2004; Conzelmann \& Nagel, 2003). Obtaining education during an athletic career can be seen as a form of preretirement planning, which has been stressed as a significant factor in adaptation to athletic retirement (Kadlcik \& Flemr, 2008; EC, 2012).

A significant body of research has been accumulated on athletic career, examining career development, transitions, and especially athletic retirement (see Stambulova, Alfermann, Statler \& Côté, 
2009, for a review). Contemporary research emphasizes the need for "whole career" and "whole person" approach, highlighting that athletes go through several transitions in sport, education, and psycho-social development simultaneously (Wylleman \& Lavallee, 2004). Dual career research is a response to the call for this holistic approach and it has become a growing area of study (e.g., Aquilina \& Henry, 2010; Burnett, 2010; Dustan-Lewis \& McKenna, 2004; Jonker, Elferink-Gemser \& Visscher, 2009; McGillivray, 2006; Platts \& Smith, 2009; Sørensen \& Christensen, 2009). Athletes' dual career has recently received attention also from the European Union (EAS n.d.; EOC, 2011; EC, 2012). The two recent documents, EU Guidelines on Dual Career of Athletes (Guidelines) (EC, 2012) and the Guidelines - Promoting Dual Career in the EU (DCG) (EOC, 2011), highlight the supportive approach of the EU towards dual career. It is stressed that the traditions in various policy fields in Member States are respected and that the Guidelines intend to respect cultural diversity. There is also an appeal to national authorities to develop culturally and country-specific guidelines for dual career that would take into account the Guidelines but also the specificities of the national education systems and sports (EC, 2012). While dual career support has been more developed in the old Member States (e.g., Denmark, Finland, France, Germany, Sweden, the UK) (EC, 2012), also the new Member States have recently shown recognizable will to take action in dual career support. Estonia, Poland, Romania, Slovakia, and Slovenia support this trend by being involved in the INTECS Network, which focuses on dual careers of professional winter sports athletes (RAMK, 2010). Romania and Slovenia show similar effort by being members of the FIFPro Online Academy, which is a program of online education organized for professional football-players (FIFPro n.d.).

In recent years, several researchers have voiced the need for a culturally-specific approach in career research in sport psychology (e.g., Burnett, 2010; Lupo et al., 2014; Stambulova \& Ryba, 2013). That is, in order to understand athletes' career behavior, researchers need to address the various contexts, cultural attitudes, and social institutions such as national sport federations that provide athletes with certain resources while limiting others. Cultural awareness is central also when attempting to create dual career support programs (Burnett, 2010) and the cultural aspects should be made known to stakeholders in order to make the programs efficient. This would lead to the establishment of efficient policies and support programs that would secure a possibility for success both in athletic career and in education (McGillivray, 2006; Platts \& Smith, 2009).

The aim of the present study was to gain insight to Slovak athletes' personal experiences of dual career. As a national context which has not been examined in previous dual career research, this study has the potential to bring new culturally-specific knowledge of athletes' career trajectories and the role of education and/or work while pursuing an athletic career. Secondly, our aim was to compare the actual experiences of athletes with the EU guidelines and examine whether these guidelines are in effective use. In the following, we review the existing literature on dual career, continue with our empirical insights from phenomenological interviews, and present our key findings. Finally, we evaluate the state of dual career practices in Slovakia and finish with recommendations for research and implementation of dual career support programs.

\section{Literature Review}

In the last decade, dual career has become a visible topic in athletic career research across the world. European studies addressing dual career can be divided into two areas: first, the policies and structures in EU countries that support dual career (Aquilina \& Henry, 2010; Borggrefe \& Cachay, 2012; Caput-Jogunica, Ćurković \& Bjelić, 2012; Honta, 2007; Platts \& Smith, 2009), and secondly, athletes' personal experiences of combining an athletic career with studies or work (Aquilina, 2013; Corrado, Tessitore, Capranica, Rauter \& Topic, 2012; Dustan-Lewis \& McKenna, 2004; Jonker et al., 2009; McGillivray, 2006; Sørensen \& Christensen, 2009).

A recent review of policy and practice in higher education in EU Member States concerning elite athletes (Aquilina \& Henry, 2010) identified four positions: a) state-centric provision, b) the state formally 
connecting educational and sport bodies, c) national sport organizations directly contacting educational bodies, and d) no formal structures. The review was based on fieldwork from 25 Member States (Bulgaria and Romania were not included) and revealed several well-functioning dual career support structures (e.g., in Denmark, Germany, Hungary, Italy, the Netherlands, and the UK). The review included few details on how dual career unfolds in Slovakia, and the Slovak approach towards educational services for elite athletes in higher education was characterized as laissez faire: no formal structures. Another extensive study by CaputJogunica and colleagues (2012) analyzed the role of universities in athletes' dual career across the EU. They identified specific practices in Europe such as admission of Olympic athletes to any university or college without entrance examination (Hungary), scholarships for athletes on the Olympic list (Belgium - Flanders), annual scholarships (Greece), and The Talented Scholarship Scheme (TASS) (United Kingdom). They pointed out that the development of dual career support systems is at different levels between EU countries and stressed the importance of flexibility in studies for a successful dual career.

In the nation-specific studies on structures that support dual career, Borggrefe and Cachay (2012) examined the "Verbundsystem" in Germany which creates cooperation between schools and organized sports. Structural coupling was claimed to be attractive for elite sport, whereas for schools it was rather problematic, as it demanded certain adjustments such as reorganization in the curriculum to include the training sessions and smaller classes than in regular schools. They also argued that it was important to include training in the curricular content in order to make cooperation effective. In France, Honta (2007) found that different educational institutions have their own habitual ways of action, which are difficult to modify so as to serve the dual career purpose (e.g., tolerating students' absences, creating extra teaching assistance for them). This diversity created tension, but all stakeholders agreed that there is a need for coordination in the matter. Finally, Platts and Smith (2009) examined the education and welfare of young professional footballers in England. They argued that subcultural values surrounding football such as commercialization, globalization, and anti-academic attitudes may limit the efficiency of strategies that are implemented to enhance athletes' education and training.

A growing body of European studies has also focused on athletes' personal experiences of dual career. In Denmark, Sørensen and Christensen (2009) examined young soccer players' experiences of combining their school and sport responsibilities. The study showed that players were strongly attracted to elite football, but experienced external pressure to complete their education. The facilitative factors in dual career were found to be little need to use transport and short distances between school, club, and home, good academic abilities, and social support. In a similar vein, Dustan-Lewis and McKenna (2004) found that student-athletes at a British university experienced a conflict between their student and athlete role. These athletes reported lack of understanding from academics and judgments about their intellectual and academic commitment, a limitation of "normal" life due to being elite athletes and, in some cases, sport as their main priority over academic work. However, research from the Netherlands has shown that dual careers can also be experienced as well manageable, and that athletes may benefit in their academic studies from their skills gained through sport (Jonker et al., 2009).

In examining motivation for pursuing a dual career, Aquilina (2013) found eight main reasons identified by Finnish, French, and British athletes: the need to focus on more than one aspect of life, belief in transferability of skills, intellectual stimulation, a sense of balance, frustration from exclusive dedication of time, a feeling of security from gaining qualifications for the future, consideration of athletic retirement, and better athletic performance in a sport friendly academic environment. Another study with Italian and Slovenian athletes (Corrado et al., 2012) found that motivational orientation for pursuing dual career were independent from gender and the reported insufficiencies in institutional support. McGillivray (2006) found that the importance of education for Scottish football players increased when the possibilities for a secure income from football decreased. It was also found that a dual career support program helped in motivating professional footballers to pursue education during their athletic career. 


\section{Methodology and Design}

The approach used in our interviews and data analysis was Interpretative Phenomenological Analysis (IPA) (Smith, Larkin \& Flowers, 2009). IPA is a qualitative approach mostly used in health psychology, but its use has been expanding to other research areas, such as applied social and clinical psychology (Reid, Flowers \& Larkin, 2005). IPA examines the participant's lifeworld in detail and explores participants' personal perception of a phenomenon (Smith et al., 2009). Participants of IPA studies are chosen because of their expertise on the studied phenomena and the data is most often collected with in-depth semi-structured interviews. Furthermore, IPA studies prefer small research samples and even case studies with a single participant in order to provide space for detailed, in-depth examination of the participants' experiences (Larkin, Eatough \& Osborn, 2011; Smith et al., 2009). IPA attempts to take an "insider's" perspective on the phenomenon (Pringle, Drummond, McLafferty \& Hendry, 2011) while simultaneously acknowledging that such perspective cannot be fully achieved, as the researcher can never completely understand the lifeworld of the participant. Therefore, the research process involves a double hermeneutic (Smith, Jarman \& Osborn, 1999) of interpretive activity, where the interviewee first interprets his or her experiences in the narration, and secondly, the researcher interprets the participant's story. The analysis in IPA studies is inductive in nature and seeks to refrain from pre-existing categories. In the analysis, transcripts are first analyzed individually and then compared across cases to capture the essential aspects of the phenomenon.

\section{Participants}

Consistently with the preference of small sample sizes in IPA, the study participants were five Slovak athletes (pseudonyms: Dalibor, Julia, Kamila, Lenka, and Marek), who had experienced dual career while participating in skiing, canoe, tennis, and volleyball. Two athletes were Olympic athletes and three were of international or high national level.

Table 1. Participants were identified through the first author's personal networks and purposeful sampling

\begin{tabular}{lll} 
Name & Sport status & Type of dual career \\
\hline Dalibor (M) & A & university/work + sport \\
Julia (F) & P & university + sport \\
Kamila (F) & P & university + sport \\
Lenka (F) & A/R & university + sport \\
Marek (M) & A & university + sport
\end{tabular}

The Republic of Slovakia is a small country in Central Europe, with a population of 5,477 million. The official language is Slovak. The country gained independence in 1993 as a consequence of the Velvet Revolution in 1989 that took place in former Czechoslovakia. Slovakia became a member of the EU in 2004. As a special structural aspect of the Slovak sport system, there are three organizations that employ professional athletes: Dukla - the military sports center (regulated by the Ministry of Defense), the National Sports Representation Centre of the Ministry of Interior, and the National Sports Centre (regulated by the Ministry of Education). These centers employ elite athletes, both full-time and part-time, according to their results in international competitions (Sport, 2013; Sport Slovakia, 2009a; Sport Slovakia, 2009b).

\section{Data Collection}

All participants were interviewed once by the first author. The semi-structured interviews were conducted in Slovak and lasted between 95 and 114 minutes, with an average of 105 minutes. Consistently with the principles of phenomenological research, the participant was considered an expert of the 
investigated phenomenon; therefore, the interview guide served as a supportive tool rather than a dictating one, and its order was not necessarily followed (Dale, 1996).

The first author knew four of the participants prior to the interviews, which helped her in establishing contact and rapport with the participants. She received her education at the same sports gymnasium as three of the participants and a Slovak university, which made her familiar with the educational structures in Slovakia. The second author was not a cultural insider and served as a "critical friend" (Wolcott, 1995) who could point out some culture-specific aspects in the participants' experiences and the dual career structures in Slovakia. The combination of emic and etic perspectives provided both closeness and relatedness to the participants' experiences as well as analytical distance, which helped in discerning some taken-for-granted assumptions in the studied culture.

\section{Data Analysis}

The data analysis was conducted according to the steps outlined by Smith and Osborn (2007). First, all interviews were transcribed verbatim and translated into English. Then, the first author read the transcripts 34 times and wrote initial notes and comments in the margins. As the next step, she developed the initial notes into themes, which were subsequently clustered into broader themes. The same procedure was first conducted separately with each interview, and once all cases were analyzed individually, they were compared and common themes were sought across cases. The second author coded parts of the transcripts and the coding was compared between the authors. Finally, a table of themes was created for all participants.

\section{Results}

In the analysis, we identified six main themes related to the athletes' dual career experience:

(1). Satisfaction with dual career;

(2). Personal effort in managing dual career;

(3). Motivation to start studying university;

(4). Dual career support;

(5). Unfavorable conditions;

(6). Perception of sportspeople.

Table 2. Themes that emerged from the interviews and were common for 3-5 athletes

\begin{tabular}{|c|c|c|}
\hline Themes & Subthemes & Quotes \\
\hline \multirow[t]{2}{*}{$\begin{array}{l}\text { Satisfaction with } \\
\text { Dual Career (DC) }\end{array}$} & $\begin{array}{l}\text { Sports and studies } \\
(3)\end{array}$ & L: "That was the perfect combination - play [my sport] and study”. \\
\hline & Sports and work (1) & D: "I still think I got the best out of it during the years". \\
\hline \multirow[t]{2}{*}{$\begin{array}{l}\text { Personal Effort in } \\
\text { Managing DC }\end{array}$} & In studies (4) & $\begin{array}{l}\mathrm{K}: \text { "But it's [getting prepared for classes] up to you, whether you want it } \\
\text { or not". } \\
\text { M: "It's mainly about the athlete's attitude to his studies". }\end{array}$ \\
\hline & In sports (1) & $\begin{array}{l}\mathrm{J}: \text { "[...]. even though you don't always feel like it but you have to } \\
\text { organize it. [...]. So I said I need to go to practice around } 6 \text { p.m. and } \\
\text { everything 'gave in' to it. [...].". }\end{array}$ \\
\hline \multirow[t]{4}{*}{$\begin{array}{l}\text { Motivation to } \\
\text { Start Studying at } \\
\text { University }\end{array}$} & Security (2) & $\begin{array}{l}\text { L: "[...]. you can make a living out of it if you are a top } 100 \text { player } \\
\text { [...].And I had this opportunity to get good education so it wasn't such } \\
\text { a risk like going somewhere and fighting your way through } \\
\text { tournaments". }\end{array}$ \\
\hline & Backup (2) & $\begin{array}{l}\mathrm{K}: \text { "Because when I stop doing sports what am I going to do with only a } \\
\text { degree from high school [...].?" }\end{array}$ \\
\hline & Parents (1) & $\begin{array}{l}\text { D: "And, of course, there was the ambition of my parents for me to go to } \\
\text { university". }\end{array}$ \\
\hline & Team (1) & L: "[...]. I really liked team spirit and I knew that there there'd be girls, \\
\hline
\end{tabular}




\begin{tabular}{|c|c|c|}
\hline & & that it'd be a team". \\
\hline \multirow[t]{5}{*}{$\begin{array}{ll}\text { Dual } & \text { Career } \\
\text { Support } & \end{array}$} & Peers (4) & $\begin{array}{l}\text { I: "What helped you the most to manage the demanding schedule?" } \\
\text { D: "Probably the fact that I wasn't alone in it. We were a training group } \\
\text { so it was not only me having those obligations". } \\
\text { "[...]. after all these years in the sport [...].[ y] ou always have somebody } \\
\text { to complain about things. [...]. And in the evening sitting with a beer you } \\
\text { talk about things, complain and next day it's cool again". } \\
\text { J: "[...]. any time I go to the dock, there's always somebody around. And } \\
\text { I enjoy practicing more". } \\
\text { M: "We really stood together like a group. That was pushing us } \\
\text { forward". }\end{array}$ \\
\hline & Employers (3) & $\begin{array}{l}\text { D: "[...]. I was lucky [...]. I had such an employer that basically fired me } \\
\text { when I needed to leave.". } \\
\text { K: "[...]. in (sports center A) [...]. there was big, big support. They } \\
\text { wanted me to study and do sports". }\end{array}$ \\
\hline & Parents (3) & $\begin{array}{l}\text { L: "Family is in the first place undoubtedly". } \\
\text { M: "Perfect. I always had support and still have ... From my parents, my } \\
\text { grandparents". }\end{array}$ \\
\hline & School (1) & $\begin{array}{l}\text { L: "The school [...]. made it possible for me to practice or to have } \\
\text { a certain training plan and be allowed to miss lessons". }\end{array}$ \\
\hline & Coaches (1) & $\begin{array}{l}\text { M: "They [the coaches] were supportive as long as we weren't absent } \\
\text { from practices. [...]" }\end{array}$ \\
\hline \multirow[t]{5}{*}{$\begin{array}{l}\text { Unfavorable } \\
\text { Conditions }\end{array}$} & Finances (3) & $\begin{array}{l}\text { D: "My parents had to finance everything [...] my parents ceased being } \\
\text { able to handle it". }\end{array}$ \\
\hline & $\begin{array}{l}\text { Inflexibility } \\
\text { studies (1) }\end{array}$ & $\begin{array}{l}\text { D: "[...]. at (school subject) [...] there wasn't the will to communicate or } \\
\text { find a solution together so that I could combine it with sport". }\end{array}$ \\
\hline & $\begin{array}{l}\text { Faculty's negative } \\
\text { approach towards } \\
\text { DC (2) }\end{array}$ & $\begin{array}{l}\text { K: "I was so pissed that time [...]. One teacher told me: 'How can you } \\
\text { want to be an academician, a student, and do your sport at the same } \\
\text { time? That's impossible!'” } \\
\text { D: "After the first packed year, the next year was even more packed and } \\
\text { I was told: 'Either you are going to do sports or you are going to } \\
\text { study.," }\end{array}$ \\
\hline & Loneliness (4) & $\begin{array}{l}\text { J: "It's manageable [training alone] but not in the long-term [...]. } \\
\text { I couldn't go on like that anymore". } \\
\text { L: "I'm not a person that will just go for a run just like that. I needed } \\
\text { company and people and it was very difficult". }\end{array}$ \\
\hline & $\begin{array}{l}\text { Limited structured } \\
\text { DC support (3) }\end{array}$ & $\begin{array}{l}\text { K: "No one was able to answer my questions and I was going from door } \\
\text { to door [...]. they were simply not prepared for a professional athlete". }\end{array}$ \\
\hline \multirow[t]{2}{*}{$\begin{array}{l}\text { Perception of } \\
\text { Sportspeople }\end{array}$} & $\begin{array}{l}\text { Personal } \\
\text { identification (1) }\end{array}$ & $\begin{array}{l}\text { D: "[...] you know how the physical education students are perceived at } \\
\text { university (laugh). [...]. So it was not far from the truth. [...]. Deciding } \\
\text { between going to a lecture and going downtown for a coffee, of course, } \\
\text { we went for the coffee. [...]. Everybody saw us as dumbheads". }\end{array}$ \\
\hline & $\begin{array}{l}\text { Prejudice } \\
\text { teachers }(3)\end{array}$ & $\begin{array}{l}\text { M: "When they [the professors] saw 'physical education' they were like: } \\
\text { 'Jesus Christ!' At some courses it was just impossible to get a better } \\
\text { grade. It was impossible”. }\end{array}$ \\
\hline
\end{tabular}

\section{Satisfaction with Dual Career}

Julia, Kamila, and Lenka appeared to be more satisfied with their dual careers than Dalibor and Marek. The main reasons for this appeared to be financial security, special arrangements for state-hired professional student-athletes (Julia and Kamila), perceived future job opportunities, and trust in one's personal skills in managing the demanding schedules. It was clear that the professional athletes were more satisfied with their situation than the non-professional athletes, who could not fully focus on their sport without the need for another job. The professional athletes Julia and Kamila considered themselves privileged in comparison with other athletes and mentioned examples such as a stable salary and study arrangements, which other athletes were not provided. Julia used the word "advantage" very frequently in her speech to indicate her resourceful conditions. Kamila expressed compassion for successful athletes that 
did not have her benefit of studying via distance studies, because they did not have a medal from European or the World Championships.

The non-professional athletes, on the other hand, had to either find a job on the side of their studies and sport, or rely on the support of their parents. Lenka (business-related studies) had been employed since she finished college and therefore was financially secure. Marek, on the other hand, was experiencing difficulties in finding a job matching his education in sport science. Dalibor had a job that was not related to his studies and he had the most negative perception of dual career. He mentioned that he was more satisfied with his dual career as a combination of sport and work than the combination of sport and studies. In his job, he could take leave for a period of time when he needed more time for sport, while such flexibility was not possible with his studies at university. Moreover, his athletic goals had become more serious than they had been in the first years of university. The arrangement where he could "jump on and off" from his job had been an individually arranged, special condition rather than a consequence of structured dual career support.

Perception of personal competencies was also a significant factor in satisfaction with dual career. Julia reported that she managed her dual career at university with relative ease and confidence. Her personal qualities of responsibility, skillfulness, and learning abilities were seen as the main contributors to her successful dual career. She was glad she had finished a university degree during her athletic career and claimed it had been manageable despite occasional stress and difficulties. Lenka had enjoyed combining sport with her studies. She stated it had been a "perfect combination" that enabled her to rest from her sport or studies accordingly. She thought that dedicating herself to two activities worked better for her rather than only focusing on one.

\section{Personal Effort in Managing Dual Career}

All athletes felt that personal effort was a significant factor in managing dual career. This was either through good organization, such as efficient time management, or discipline and responsibility towards one's tasks. Personal effort was also mentioned in the form of assertiveness and developed communication skills. Dalibor admitted he could have invested more effort into his studies had he been less indifferent towards them. Julia illustrated her discipline in planning the time of her practice and being punctual in fulfilling the training plan. Furthermore, she mentioned that she did not expect things to be easy or "served" to her and rather faced difficulties with determination. Marek highlighted the importance of being proactive and communicating one's dual career needs at the right moment, which he saw as the key to dual career success.

\section{Motivation to Start Studying University}

Julia, Kamila, Lenka, and Marek mentioned security for the future as the main motive for university education. They perceived their university degrees as an important backup for their lives after a competitive athletic career. Dalibor, however, did not see university education as a major advantage for his future, and for him parental pressure had been the main reason to take up studies. Despite positive regard toward education among other participants, worries related to finding a job in their study field and lack of work experience were also present in their accounts. Only Lenka, who had obtained a business-related degree in the United States, did not express worries concerning her employment, and she already had work experience from her field both from the U.S. and Slovakia. Three participants who had studied sports science mentioned the lack of sport-related full-time occupations as one concern of their future employment.

\section{Dual Career Support}

Participants mentioned receiving some forms of support from employers, family, coach, peers, and/or educational institutions. Parents and family were mentioned by Julia, Lenka, and Marek as significant supporters in their dual career emotionally and sometimes also financially. Dalibor even mentioned choosing a less attractive study program in order to stay close to his family and network. Lenka considered her sports 
gymnasium as a significant support to her dual career by adjusting her schedules and tolerating absences. Marek mentioned having understanding coaches in his sport club; Dalibor, Julia, and Kamila had also received support from their employers.

The individual sport athletes (Kamila, Lenka, Julia, and Dalibor) mentioned the importance of peers in training and mentioned loneliness as a downside of elite sports. The only team athlete, Marek, did not mention loneliness or the importance of peers in sport, which may have been due to the taken-for-granted presence of others in training. The presence of peers was important not only in sports but also in education, both at the sports gymnasium and at university. Dalibor mentioned that peers helped him mentally manage the demanding schedule of the sports gymnasium, and Marek talked about the support they used to give each other in his study group at university during hard periods.

Kamila, who studied at university in a distance learning program tailored for professional athletes, was thankful for the special arrangement she had with her studies, but at the same time expressed the desire to have had more peers in her university group. The downside of the distance studies was that most of the times she had to study alone, which made her feel that she missed out on some aspects of university life.

\section{Unfavorable Conditions}

While the state-hired professional athletes were mainly satisfied with their arrangements, others had significant problems mainly related to finances, inflexibility of studies, and limited structured dual career support. Dalibor had to quit his dual career before starting high school because of insufficient financing of his sport. When he made a comeback to competitive sport at university, he faced unwillingness from some professors that were not open to finding alternative solutions for his course attendance. Marek mentioned the need to secure a living and think about the future of alternatives. His sport did not appear to provide him a security for the future, which slightly shifted his athletic career to the background. Both Dalibor and Kamila mentioned that some teachers had told them to choose between sport or education, because they perceived dual career as unachievable.

A common theme in participants' accounts was the lack of structure within dual career support in Slovakia. Lenka, who had migrated to the U.S. to pursue dual career, assumed that she would have had to quit her sport if she had chosen an education in Slovakia. Julia and Dalibor mentioned that their dual careers had been mainly managed by themselves, and they would have appreciated some organized support. Dalibor's dual career at the time of the interview concerned the combination of sport and work, which gave him a very demanding schedule. Kamila, who was in a special dual career program for professional athletes, also mentioned that as her distance studies program had only three students, they were sometimes "invisible" to the faculty's administration, which caused organizational difficulties.

\section{Perception of Athletes and Sport Science Students}

Dalibor, Lenka, and Marek talked about how the fact that they were student-athletes or sport science students shaped the way they were perceived by teachers, professors, and university staff. Dalibor expected the researcher to know about sports science students' low reputation, which indicates that he assumes it was a broad phenomenon that occurs not only at his university. He related himself to this reputation and identified himself with it, admitting he had been an indifferent student at university and had focused more on the "fun of it". On the other hand, Lenka and Marek did not feel these stereotypes were justified and they had suffered from these attitudes. Some teachers at Lenka's sports gymnasium had expressed wonder about her being at that school once she was a good and smart student. The teachers' surprise had made her feel sorry and she considered it unreasonable. She mentioned that the perception of student-athletes was different in the U.S., where her athletic career during her studies was valued and appreciated more than being a regular student. Moreover, Marek mentioned that he felt that it was impossible to get top grades as a sport science student at his university due to teachers' prejudice. 


\section{Discussion}

Our results suggest that dual career is sometimes a challenging pursuit for Slovak students, and at the moment they rely more on their skills and personal effort rather than an organized support system. Similar to previous studies, we found that on occasion, the student and athlete roles may be conflicting (Sørensen \& Christensen, 2009), and that some athletes may prioritize sport over educational success (McKenna \& Dustan-Lewis, 2004). Nevertheless, in other cases the athlete's role may be also enhance the student role (Jonker et al., 2009). The motivations of our participants to study at university such as backup and security were also identified by Aquilina (2013), and the pursuit of security of an income after athletic retirement was previously found by McGillivray (2006). External pressure from family to gain education was also mentioned by Sørensen and Christensen (2009).

The study gave insight into the perception of student-athletes, which is previously mentioned in only one European article (McKenna \& Dustan-Lewis, 2004). Our findings suggest that in Slovakia, athletes may be facing a negative mindset towards the dual career concept by their educational institutions, which may be a challenge to overcome in seeking to implement dual career support programs. One reason for this may be the lack of knowledge about dual career demands, which leads to some academics being skeptical about student-athletes increased support (Dustan-Lewis \& McKenna, 2004). Additionally, the current results contain personal identification with the negative perception of athletes, confirming that some are living up to the expectations of the teachers and rather going for a coffee than attending their lectures. The diversity of our participants' motives and actual engagement with their studies shows that a personalized approach is needed when trying to find working solutions for student-athletes.

The athletic careers of some of our participants were shown to be not to linear. That is, their investment in sport changed over time according to financial situation, work duties, and educational commitments. This was truer with the non-professional athletes, who often had to negotiate their athletic careers within limited financial resources. This unlinear career progression in sport has been rarely noted in existing scholarship. Yet, it points towards the importance of holistic approach in career research, which accounts for different spheres in athletes' lives (Wylleman \& Lavallee, 2004; EC, 2012).

Currently, only the few professional athletes in Slovakia have dual career structures in place - others need to find other less-structured ways in pursuing dual career. That is, only athletes who have achieved first to third position at the European or World Championships are admitted into distance studies. This highly competitive system may create tension between student athletes and result in some ambitious athletes dropping out of their higher education because of their athletic commitments. For those who are not at the elite level by the time they start their university studies, there seems to be a laissez faire (no formal structures) type of approach (Aquilina \& Henry, 2010) towards athletes' education in Slovakia.

\section{The Guidelines and the Findings of the Current Study}

The experience of dual career appeared as a generally manageable process if there were some arrangements in place that enabled education or occupation to be adjusted to practices, camps, and competitions. This is in compliance with the Guidelines in which it is stated that dual career is usually achievable only with the help of supporting services and a balanced performance team (EC, 2012). The athletes in the study appreciated when educational and employing institutions had created conditions that helped the smooth combination of their athletic career with their studying or work duties - yet, this was not always the case for non-professional athletes. For the very elite athletes, there were official and state-based structures, such as the schedule structure of distance studies and employment as a professional athlete. Some other solutions were individually or unofficially arranged using a personal agency, including modified course contents and intermittent employment. However, athletes did not seem to have received substantial dual career support from businesses or national sport organizations. The Guidelines address this issue by encouraging sport organizations to review their policies and to be open to dual career development (EC, 2012). There is still substantial work to be done in order to have these structures in place in Slovakia. 
The athletes' worries about decent sport-related work after athletic retirement are addressed in the Guidelines through a call for structured support in helping elite athletes transfer to other professions in sport (EC, 2012). The Guidelines further mention that extra "holidays" (competition and training camps) are often a problem for athletes that work full-time (EC, 2012). This was confirmed to be a practical problem also in this study. The Guidelines also mention discrimination against athletes with disabilities, as some countries have different funding policies for them compared to able-bodied athletes (EC, 2012). This situation was mentioned by one of our participants who worked as a guide for a disabled athlete. Future work should seek to address this issue.

\section{Conclusion}

The purpose of this research was to examine how Slovak athletes experience dual career. As such, the present study contributes to the recent expansion in dual career research into the new EU Member States. As a national context unexplored in previous research, this study provided new insight into the experiences of athletes originating from Slovakia and whose athletic careers had mainly developed within this country.

The participants considered dual career to be achievable, but several challenges were also identified. Dual career support during university appeared to be well established only for the very elite athletes, while others faced challenges in handling the demands of sport and education. Participants used different ways to manage dual career, but only few of these strategies were officially grounded. The negative perception of athletes and sports students by educational representatives appeared to be a deficiency in the athletes' environment. These prejudices should be taken into consideration when seeking to develop structured dual career support for high-level Slovak athletes. Establishing good relationships between educational institutions and sport organizations is essential for developing effective dual career structures in Slovakia.

Our study did not focus on the type of our participants' sports and this might have left some sportspecific phenomena that influence dual career unrevealed. For example, in those sports where there are little possibilities for saving money from the earnings of an athletic career, athletes may feel a more profound need to obtain education. Therefore, future research should also account for sport-specific features that affect athletes' decision to pursue dual career. Moreover, previous research on stereotyping in sports mainly deals with stereotypes related to sexuality, race, ethnicity, and gender and is prevailingly grounded in the U.S. context. More research on the stereotypes or prejudice created among teachers, professors, and faculty towards athletes and sportspeople could provide a better understanding of the study environments that athletes are facing.

Our participants identified several ways of supporting them and others pursuing dual career:

1. Providing athletes with distance studies study groups;

2. Finding ways of changing the stereotypes of teachers and faculty about sportspeople (athletes and sports students);

3. Enhancing the structure of dual career support;

4. Creating new dual career programs especially to support the accomplishment of a meaningful educational degree.

However, these young adults were also aware of the importance of personal effort for successful dual career and were not playing the victim's role despite some unfavorable conditions. Finally, to allow for successful dual career that provides skills and qualifications for post-retirement life, it is important to maintain the quality of athletes' studies and not lower it for the sake of their athletic careers - making both possible while keeping the quality of both parts (education/job and athletic career) high. 


\section{REFERENCES}

Amara, M., Aquilina, D. \& Henry, I. (2004). Education of young sportspersons (lot 1). Report Finale. Brussels: Directorate-General Education and Culture. Retrieved from http://ec.europa.eu/sport/library/documents/c3/pmp-studydual-career_en.pdf

Aquilina, D. (2013). A study of the relationship between elite athletes' educational development and sporting performance. International Journal of the History of Sport, 30, 374-392.

Aquilina, D. \& Henry, I. (2010). Elite athletes and university education in Europe: A review of policy and practice in higher education in the European Union Member States. International Journal of Sport Policy, 2, 25-47.

Aries, E., McCarthy, D., Salovey, P., \& Banaji, M.R. (2004). A comparison of athletes and non-athletes at highly selective colleges: Academic performance and personal development. Research in higher education, 45(6), 577-602.

Borggrefe, C. \& Cachay, K. (2012). "Dual careers": The structural coupling of elite sport and school exemplified by the German Verbundsysteme. EJSS. European Journal for Sport and Society, 9, 57.

Burnett, C. (2010). Student versus athlete: Professional socialisation influx. African Journal for Physical, Health Education, Recreation \& Dance, 193-203.

Caput-Jogunica, R., Ćurković, S. \& Bjelić, G. (2012). Comparative analysis: Support for student - athletes and the guidelines for the universities in Southeast Europe. Sport Science, 5, 21-26.

Conzelmann, A. \& Nagel, S. (2003). Professional careers of the German Olympic athletes. International Review for the Sociology of Sport, 38(3), 259-280.

Corrado, L., Tessitore, A., Capranica, L., Rauter, S. \& Topic, M.D. (2012). Motivation for a dual-career: Italian and Slovenian student-athletes/motivacija za dvojno kariero: Italijanski in slovenski studenti sportniki. Kinesiologia Slovenica, 18, 47.

Dale, G.A. (1996). Existential phenomenology: Emphasizing the experience of the athlete in sport psychology research. Sport Psychologist, 10, 307-321.

Dunstan-Lewis, N. \& McKenna, J. (2004). An action research approach to supporting elite student-athletes in higher education. European Physical Education Review, 10(2), 179.

EAS - The Dual Career Network [EAS]. (n.d.). About. Retrieved from http://www.dualcareer.eu/pages/about.html

EOC EU Office [EOC]. (2011). Guidelines - Promoting Dual Career in the EU (DCG). Athletes-To-Business. Retrieved from http://www.athletestobusiness.eu/docs/budapest/A2B_guidelines_final.pdf

FIFPro. (n.d.). Members. Retrieved from http://www.fifpro.org/division/index/1

Honta, M. (2007). Organizing the dual sporting-social project for high-level athletes in France. International Review for the Sociology of Sport, 42, 133.

Jonker, L., Elferink-Gemser, M.T. \& Visscher, C. (2009). Talented athletes and academic achievements: A comparison over 14 years. High Ability Studies, 20, 55.

Kadlcik, J. \& Flemr, L. (2008). Athletic career termination model in the Czech Republic. A qualitative exploration. International Review for the Sociology of Sport, 43, 251-269.

Larkin, M., Eatough, V. \& Osborn, M. (2011). Interpretative phenomenological analysis and embodied, active, situated cognition. Theory \& Psychology, 21, 318.

Lavallee, D. \& Wylleman, P. (Eds.). (2000). Career transitions in sport: International perspectives. Fitness Information Technology.

Lupo, C. et al. (2014). Motivation towards dual career of European student-athletes. European Journal of Sport Science, (ahead-of-print), 1-10.

McGillivray, D. (2006). Facilitating change in the educational experiences of professional footballers: The case of Scottish football. Managing Leisure, 11, 22.

Platts, C. \& Smith, A. (2009). The education, rights and welfare of young people in professional football in England: Some implications of the white paper on sport. International Journal of Sport Policy, 1, 323.

Pringle, J., Drummond, J., McLafferty, E. \& Hendry, C. (2011). Interpretative phenomenological analysis: A discussion and critique. Nurse Researcher, 18, 20.

Reid, K., Flowers, P. \& Larkin, M. (2005). Exploring lived experience. Psychologist, 18, 20.

Rovaniemen ammattikorkeakoulu (RAMK) /University of Applied Sciences/. (2010). INTECS Network Building. Retrieved from http://vanha.ramk.fi/?DeptID=15837

Smith, J.A., Jarman, M. \& Osborn, M. (1999). Doing interpretative phenomenological analysis. In Murray, M. \& Chamberlain, K. Qualitative Health Psychology. (pp. 218-240). London: SAGE. 
Smith, J.A., Larkin, M. \& Flowers, P. (2009). Interpretative phenomenological analysis: Theory, method, and research. London: SAGE.

Smith, J.A. \& Osborn, M. (2007). Interpretative Phenomenological Analysis. In Smith, J.A. (Ed.). (2007). Qualitative psychology: A practical guide to research methods. (pp. 53-80). SAGE.

Sørensen, J.K. \& Christensen, M.K. (2009). Sport or school? Dreams and dilemmas for talented young Danish football players. European Physical Education Review, 15, 115.

Sport. (2013, June 27). Kol'ko zarábajú naši špičkoví štátom platení športovci vo vrcholových strediskách? /What is the income of our state paid top athletes in elite sport centres?/. Retrieved from http://sport.aktuality.sk/c/151500/kolkozarabaju-nasi-spickovi-statom-plateni-sportovci-vo-vrcholovych-strediskach/

Sport Slovakia. (2009a). Slovensko a šport /Slovakia and Sport/. Retrieved from http://www.sportslovakia.sk/web/index.php?option=com_content\&view=article\&id=48\&Itemid=18\&lang=sk

Sport Slovakia. (2009b). Z histórie športu na Slovensku /From the History of Sport in Slovakia/. Retrieved from http://www.sportslovakia.sk/web/index.php?option=com_content\&view=article\&id=47\&Itemid=29\&lang=sk

Stambulova, N., Alfermann, D., Statler, T. \& Côté, J. (2009). ISSP position stand: Career development and transitions of athletes. International Journal of Sport and Exercise Psychology, 7, 395-412.

Stambulova, N., Stephan, Y. \& Japhag, U. (2007). Athletic retirement: A cross-national comparison of elite French and Swedish athletes. Psychology of Sport \& Exercise, 8, 101.

Stambulova, N.B. \& Ryba, T.V. (2013). Athletes' careers across cultures. London: Routledge.

Wolcott, H.F. (1995). The art of fieldwork. Walnut Creek: Altamira.

Wylleman, P. \& Lavallee, D. (2004). A developmental perspective on transitions faced by athletes. In Weiss, Maureen R. (Ed), Developmental sport and exercise psychology: A lifespan perspective (507-527). Morgantown, WV, US: Fitness Information Technology.

\section{AUTHOR'S ADDRESS: $\quad$ Kristina Geraniosova}

De Mezas Vej 7, 1. tv, 8000 Aarhus

Denmark

Email: kgeraniosova@gmail.com 